\title{
Pengaruh Keterampilan dan Kesadaran Teknologi Informasi terhadap Prestasi Belajar Mahasiswa Selama Pandemi Covid-19
}

\author{
Author: \\ Hari Anggit Cahyo \\ Wibowo $^{1}$ \\ Indrawati Wilujeng ${ }^{2}$ \\ Afiliation: \\ STKIP Al Hikmah \\ Surabaya ${ }^{1,2}$ \\ Corresponding email \\ anggitpm2013@gmail.co \\ $\mathrm{m}$ \\ Histori Naskah: \\ Submitted: 11-07-2021 \\ Accepted: 27-07-2021

Abstrak:

Latar belakang: Adanya pandemi Covid-19 berdampak pada dunia pendidikan. Pembelajaran yang sebelumnya dilaksanakan secara tatap muka langsung berubah menjadi pembelajaran daring. Keberhasilan pembelajaran daring tentunya tidak lepas dari peran teknologi informasi. Penelitian ini bertujuan untuk mendeskripsikan pengaruh keterampilan dan kesadaran teknologi informasi mahasiswa calon guru terhadap prestasi belajar selama pembelajaran daring.

Metode penelitian: Penelitian ini menggunakan metode deskriptif eksploratif dengan mendasarkan pada kajian data kuantitatif. Pengambilan data kuantitatif dilakukan dengan teknik survai menggunakan instrumen angket keterampilan dan kesadaran teknologi informasi yang telah dinyatakan valid. Data kuantitatif dianalisis dengan menggunakan korelasi linear (Person) untuk mengetahui adanya hubungan antar variabel. Analisis untuk memperoleh kesimpulan dilakukan dengan pendekatan induktif.

Hasil penelitian: Pada penelitian ini telah dirumuskan empat aspek keterampilan teknologi informasi (functional skills, creativity, collaboration and communication, and find and select information) dan dua aspek kesadaran teknologi informasi (important, value-added). Berdasarkan analisis korelasi antara masing-masing aspek yang telah dirumuskan diperoleh bahwa nilai sig. (2-tailed) selalu $>0,05$. Hasil ini menunjukkan bahwa tidak terdapat pengaruh signifikan antara keterampilan dan kesadaran teknologi informasi terhadap prestasi belajar mahasiswa.

Kesimpulan: Keterampilan dan kesadaran teknologi informasi tidak berpengaruh secara signifikan terhadap prestasi belajar mahasiswa selama perkuliahan daring. Hasil tersebut dikarenakan sistem penilaian yang komprehensif dan terintegrasi yang memadukan antara penilaian akademik, penialain interaksi edukatif, dan penilaian karakter. Keterampilan teknologi dan informasi hanya berpengaruh secara sempit kepada nilai matakuliah yang sesuai dengan aspek keterampilan teknologi informasi tersebut.

Kata kunci: Keterampilan Teknologi Informasi, Pembelajaran Daring, Prestasi Belajar, Pandemi, Covid-19

\section{Pendahuluan}

Di Indonesia pendidikan merupakan faktor utama dalam menciptakan bangsa yang cakap, bangsa yang beriman dan bertakwa kepada Tuhan Yang Maha Esa, serta memiliki pengetahuan yang baik (Sujana, 2019) sehingga dapat bersaing dengan negara-negara lain. Kualitas pendidikan seharusnya menjamin lahirnya generasi masa depan yang berkualitas dan siap beradaptasi dengan kemajuan teknologi. 
Salah satu unsur kunci dari pendidikan adalah sosok guru (pendidik). Karena itu, Pendidikan calon guru sudah seharusnya berbeda dengan pendidikan non-guru. Jika pendidikan non-guru hanya berfokus pada akademik dan kompetensi lain yang diperlukan dalam dunia kerja, maka paradigma pendidikan calon guru haruslah sedikit berbeda, calon guru harus menjadi sosok yang memiliki karakter layak dicontoh dan mampu merubah perilaku peserta didik untuk menjadi manusia yang berkualitas, memiliki budi pekerti luhur, baik secara individu maupun sebagai warga negara (Afandi, 2011).

Pada masa pandemi Covid-19 telah terjadi perubahan lingkungan belajar yaitu dari pembelajaran yang bersifat tatap muka langsung (luring) menjadi tanpa tatap muka (asinkron) maupun tatap muka secara maya (sinkron) atau sering disebut pembelajaran daring. Adanya perubahan ini memiliki dampak terhadap motivasi belajar dan tentu akan mempengaruhi prestasi belajar mahasiswa (Daniel Hasibuan et al., 2020). Masalah yang timbul dalam pembelajaran daring yang dilaksanakan di rumah masing-masing mahasiswa adalah perbedaan kemampuan dalam teknologi informasi. Kemampuan yang dimaksud ini berkaitan dengan keterampilan sekaligus kesadaran dalam teknologi informasi. Sangat diperlukan apakah adanya perbedaan kemampuan ini berpengaruh terhadap prestasi belajar mahasiswa. Penelitian ini bertujuan untuk mengetahui pengaruh keterampilan dan kesadaran teknologi informasi terhadap prestasi belajar mahasiswa calon guru di Program Studi S-1 Pendidikan Fisika STKIP Al Hikmah Surabaya.

\section{Studi Literatur}

Teknologi informasi merupakan sekumpulan yang terdiri atas perangkat keras dan lunak yang menjalankan beberapa tugas pemrosesan data. Proses tersebut dapat terdiri dari merekam, mentransmisikan data, menyimpan, memanipulasi, serta menampilkan data (Makmur, 2019). Secara umum terdapat dua aspek penting dalam teknologi informasi. Pertama, teknologi informasi yaitu segala hal yang di dalamnya terdapat proses (meliputi input dan output), manipulasi, serta pengelolaan informasi. Kedua, teknologi komunikasi yaitu segala hal yang berkaitan dengan penggunaan teknologi sebagai alat bantu dalam proses dan transfer data dari perangkat satu ke perangkat lainnya. Konsep teknologi informasi muncul setelah adanya teknologi komputer (lebih cenderung pada pemrosesan data secara lokal) dan teknologi komunikasi (saat ini dikenal internet) (Mutiara, 2020). Adanya perkembangan teknologi informasi juga memberikan dampak yang luas bagi kehidupan manusia. Teknologi dapat mempermudah pekerjaan manusia sekaligus mempercepat proses-proses aktivitas sehari-hari (Zulfah, 2018). Namun demikian adanya teknologi informasi juga memiliki dampak negatif, diantaranya adalah terjadi pergeseran budaya pada masyarakat (Setiawan, 2018).

Perkembangan teknologi informasi sangatlah berpengaruh terhadap dunia pendidikan. Adanya teknologi informasi dapat menumbuhkan inovasi dalam berbagai aspek pendidikan. Misalnya, inovasi pada media pembelajaran, LMS (Learning Management System), termasuk juga inovasi pada konten pembelajaran (Muhson, 2010). Pada masa pandemi Covid-19 teknologi informasi juga membantu aktivitas pendidikan tetap berjalan meskipun dilaksanakan secara daring melalui kegiatan WFH (work from home) bagi para pendidik dan LFH (learn from home) bagi peserta didik (Komalasari, 2020), (Puspitorini, 2020).

Selama masa pandemi Covid-19 sistem pembelajaran pada Program Studi S-1 Pendidikan Fisika STKIP Al Hikamh dilaksanakan secara daring. Pembelajaran dilaksanakan secara sinkron maupun asinkron dengan menggunakan LMS (learning management system) berbasis moodle. Perubahan sistem pembelajaran dari luring menjadi daring tentu menimbulkan beberapa gejolak baik bagi dosen maupun mahasiswa. Selain didasari oleh penguasaan teknologi informasi tantangan lain adalah pelaksanaan pembelajaran yang dilaksanakan di rumah masing-masing menimbulkan berbagai kendala baru.

Pembelajaran daring bukan tanpa kendala atau kekurangan. Karena adanya perubahan yang begitu cepat dan persiapan seadanya pembelajaran daring menurut beberapa penelitian juga dapat menimbulkan stress akademik (Andiarna, 2020). Selain itu terdapat juga hasil penelitian yang mengatakan bahwa beberapa 
mahasiswa mengalami sedikit kecemasan, stress, dan juga depresi (Hasanah et al., 2020). Permasalahan lain yang timbul adalah adanya persepsi dari peserta didik yang menganggap pembelajaran daring hanya menuntut mereka untuk belajar mandiri dan mengumpulkan tugas, sehingga peserta didik mengalami kurang motivasi dan jenuh (Sembiring, 2021).

Selama pembelajaran ditemukan bahwa kemampuan mahasiswa dalam memanfaatkan teknologi informasi sangatlah beragam. Perbedaan itu dapat terjadi karena memang penguasaan teknologi informasi mahasiswa yang memang tergolong rendah atau dikarenakan mahasiswa berasal dari daerah yang memiliki jaringan internet kurang baik. Faktor divais/alat yang dimiliki oleh mahasiswa juga sangat mempengaruhi performa selama pembelajaran daring.

Uniknya setelah melalui proses pembelajaran selama kurang lebih satu semester mahasiswa dengan penguasaan teknologi informasi yang tinggi tidak selalu memperoleh indeks prestasi (IP) belajar yang tinggi. Oleh karena itu kiranya perlu dilakukan penelitian untuk mengetahui penjelasan teoritis dan praktis di lapangan tentang fenomena tersebut. Penelitian ini bertujuan untuk mendeskripsikan dan mengeksplorasi pengaruh keterampilan dan kesadaran teknologi informasi terhadap prestasi belajar mahasiswa Program Studi S-1 Pendidikan Fisika STKIP Al Hikmah Surabaya.

\section{Metode Penelitian}

Penelitian ini menggunakan metode deskriptif eksploratif yang didasarkan pada data kuantitatif. Penelitian eksploratif bertujuan untuk menggali secara luas tentang hal-hal atau sebab yang dapat mempengaruhi terjadinya sesuatu (Arikunto, 2016). Data kuantitatif diambil dengan teknik survai. Data tersebut kemudian diolah untuk melihat nilai signifikansi korelasi antara variabel terhadap variabel yang lain. Analisis untuk memperoleh kesimpulan dilakukan dengan pendekatan induktif. Penelitian ini bertujuan untuk memperoleh informasi gambaran umum keterampilan dan kesadaran teknologi informasi mahasiswa dan pengaruhnya terhadap prestasi belajar selama masa pembelajaran daring pandemi Covid-19. Khusus untuk mahasiswa calon guru fisika di STKIP Al Hikmah Surabaya. Penelitian ini dilaksanakan di STKIP Al Hikmah Surabaya pada program studi S1 Pendidikan Fisika, pada semester gasal tahun akademik 2020/2021.

Lingkungan subjek penelitian (environment), mahasiswa di perguruan tinggi tersebut disiapkan untuk menjadi calon pendidik profesional (guru) dengan memiliki kompetensi keguruan yang handal serta memiliki karakter yang unggul. Pada perguruan tinggi tersebut tidak bisa dipisahkan antara kemampuan akademik, keterampilan sebagai seorang guru, dan karakter. Sehingga pada proses pengambilan data faktor lingkungan tersebut tidak bisa diabaikan.

Sistem perkuliahan di Program Studi S-1 Pendidikan Fisika bersifat integratif, dimana sistem penilaian tidak hanya mengacu pada penilaian akademik dalam proses perkuliahan akan tetapi juga mengacu pada penilaian kegiatan-kegiatan lain yang terintegrasi. Pertama kegiatan perkuliahan yang dilakukan sebagaimana kurikulum amanahkan, yaitu membentuk kompetensi dalam bidang fisika. Perkuliahan dilaksanakan dalam bentuk tatap maya (daring) baik dilakukan secara sinkron maupun asinkron. Kedua kegiatan interaksi edukatif dimana mahasiswa melakukan interaksi ke sekolah secara bertahap dimulai dengan hanya mengamati performa mengajar dari seorang guru profesional hingga melakukan praktik mengajar di sekolah. Kegiatan ini dilaksanakan pada setiap semester sejak semester pertama hingga semester delapan. Ketiga penilaian karakter secara holistik yang dilakukan oleh pengasuh di asrama. Namun, selama pandemi aktivitas asrama dilaksanakan di rumah masing-masing dengan rincian kegiatan dan penilaian yang sudah ditentukan. Kegiatan ini bertujuan untuk terus menerus menumbuhkan dan mengembangkan karakter mahasiswa yang sesuai dengan karakter atau kriteria calon guru yang baik. Untuk memudahkan dalam peninjauan peneliti melakukan klasifikasi keterampilan teknologi informasi yang dimaksud kedalam empat aspek yaitu: 
1 Keterampilan fungsional (Functional Skill) yaitu pengetahuan mahasiswa dalam hal operasional teknologi informasi secara umum meliputi hardware dan software, cara mengoperasikan, cara melakukan penelusuran informasi, pemrograman.

2 Kemampuan berkreasi dengan memanfaatkan teknologi informasi (Creativity) yaitu kemampuan mahasiswa dalam berkarya dengan memanfaatkan teknologi informasi, misalnya kemampuan membuat power point yang baik, sound editing, video editing.

3 Kolaborasi dan Komunikasi (Collaboration and Communication) yaitu mahasiswa mampu memanfaatkan teknologi informasi untuk berdiskusi, bertanya, atau menguji ide dan karyanya dengan orang lain.

4 Menemukan dan memilih informasi (find and select information) yaitu kemampuan mahasiswa dalam memanfaatkan teknologi informasi dalam rangka menemukan serta memilih dan memilah informasi yang akan digunakan dalam berkarya dan menyelesaikan tugas.

Selain keterampilan teknologi informasi seperti yang telah disusun sebelumnya, peneliti juga meninjau dari dua aspek kesadaran teknologi informasi sebagai berikut:

1. Penting (important) yaitu mahasiswa menganggap teknologi informasi memiliki peran penting dalam hal kesuksesan seseorang baik pada tataran pelajar, mahasiswa, maupun setelah bekerja.

2. Nilai tambah (value-added) yaitu mahasiswa menyadari bahwa dengan adanya teknologi informasi memberikan nilai tambah bagi kualitas pembelajaran yang meliputi konsep, kebaruan (Up to date), menarik dan lebih fleksibel.

Instrumen yang digunakan dalam penelitian ini adalah angket keterampilan dan kesadaran teknologi informasi yang telah dinyatakan valid. Pada proses pengujian data skala yang digunakan adalah skala likert. Instrumen ini mengukur tingkat keterampilan dan kesadaran teknologi informasi berdasarkan pendapat dan persepsi dari responden. Data yang diambil kemudian diolah dengan analisis korelasi (Pearson) untuk menentukan apakah ada hubungan yang signifikan antara keunggulan di aspek tertentu yang berkaitan dengan keterampilan dan kesadaran teknologi informasi mahasiswa dengan prestasi belajar dalam hal ini prestasi belajar dilihat melalui indeks prestasi (IP).

\section{Hasil Penelitian}

Data kuantitatif kami peroleh dengan menggunakan analisis korelasi linear (Pearson) untuk mengetahui hubungan antara variabel yang satu dengan variabel yang lainnya. Berikut merupakah hasil analisis data kuantitatif hasil dari angket survai:

1. Keterampilan Fungsional terhadap Indeks Prestasi Belajar Mahasiswa.

Tabel 1. Hasil Analisis Korelasi Keterampilan Fungsional Terhadap Indeks Prestasi Belajar Mahasiswa

\begin{tabular}{llrr}
\hline \multicolumn{1}{c}{ Correlations } & & \\
\hline & & IP & FunctionalSkill \\
\hline IP & Pearson Correlation & 1 & .344 \\
& Sig. (2-tailed) & & .209 \\
& $\mathrm{~N}$ & 15 & 15 \\
\hline FunctionalSkill & Pearson Correlation & .344 & 1 \\
& Sig. (2-tailed) & .209 & \\
& $\mathrm{~N}$ & 15 & 15 \\
\hline
\end{tabular}


Edu Cendikia: Jurnal Ilmiah Kependidikan

Volume : 1 | Nomor 2 | Agustus 2021 | E-ISSN : 2798-365X | DOI: 10.47709/educendikia.v1i2.1024

Hasil analisis data didapatkan nilai Sig. (2-tailed) 0,209 >0,05 sehingga dapat dikatakan bahwa tidak terdapat hubungan yang signifikan antara keterampilan fungsional dalam IT terhadap indeks prestasi mahasiswa calon guru fisika.

2. Kreativitas memanfaatkan Teknologi Informasi terhadap Indeks Prestasi Belajar Mahasiswa.

Tabel 2. Hasil Analisis Korelasi Kreativitas Teknologi Informasi Terhadap Indeks Prestasi Belajar Mahasiswa

\begin{tabular}{llrrr}
\hline \multicolumn{1}{c}{ Correlations } & & \\
\hline & & IP & Creativity \\
\hline IP & Pearson Correlation & 1 & -.303 \\
& Sig. (2-tailed) & & .227 \\
N & Pearson Correlation & -.303 & 15 \\
\hline Sig. (2-tailed) & .272 & 1 \\
& N & 15 & 15 \\
\hline
\end{tabular}

Hasil analisis data didapatkan nilagi Sig. (2-tailed) 0,272 >0,05 sehingga dapat dikatakan bahwa tidak terdapat hubungan yang signifikan antara Kreativitas dalam IT terhadap indeks prestasi mahasiswa calon guru fisika.

3. Kolaborasi dan Komunikasi terhadap Indeks Prestasi Belajar Mahasiswa

Tabel 3. Hasil Analisis Korelasi Keterampilan Kolaborasi dan Komunikasi It Terhadap Indeks Prestasi Belajar

\begin{tabular}{llrr}
\hline & \multicolumn{1}{c}{ Correlations } & & \\
\hline & & IP & CollabComm \\
\hline IP & Pearson Correlation & 1 & .086 \\
& Sig. (2-tailed) & & .761 \\
& N & 15 & 15 \\
\hline CollabComm & Pearson Correlation & .086 & 1 \\
& Sig. (2-tailed) & .761 & \\
& N & 15 & 15 \\
\hline
\end{tabular}

Hasil analisis data didapatkan nilai Sig. (2-tailed) 0,761 >0,05 sehingga dapat dikatakan bahwa tidak terdapat hubungan yang signifikan antara Kemampuan kolaborasi dan komunikasi dalam IT terhadap indeks prestasi mahasiswa calon guru fisika.

4. Menemukan dan Memilih Referensi terhadap Indeks Prestasi Mahasiswa

Tabel 4. Hasil Analisis Korelasi Keterampilan Menemukan dan Memilih Informasi dengan Memanfaatkan Teknologi Informasi Terhadap Indeks Prestasi Belajar

\begin{tabular}{llrr}
\hline & \multicolumn{1}{c}{ Correlations } & & FindSelectInfo \\
\hline IP & Pearson Correlation & 1 & .049 \\
& Sig. (2-tailed) & & .863 \\
& $\mathrm{~N}$ & 15 & 15 \\
\hline FindSelectInfo & Pearson Correlation & .049 & 1 \\
\hline
\end{tabular}


Edu Cendikia: Jurnal Ilmiah Kependidikan

Volume : 1 | Nomor 2 | Agustus 2021 | E-ISSN : 2798-365X | DOI: 10.47709/educendikia.v1i2.1024

Sig. (2-tailed)

$\mathrm{N}$
.863

15

Hasil analisis data didapatkan nilai Sig. (2-tailed) 0,863>0,05 sehingga dapat dikatakan bahwa tidak terdapat hubungan yang signifikan antara Kemampuan Menemukan dan Memilih referensi dalam IT terhadap indeks prestasi mahasiswa calon guru fisika.

Berdasarkan hasil analisis dengan metode serupa diperoleh hasil aspek kesadaran IT terhadap indeks prestasi belajar mahasiswa sebagai berikut:

1. Dari hasil analisis korelasi antara aspek kesadaran akan pentingnya IT dalam menunjang keberhasilan dengan indeks prestasi belajar, diperoleh nilai Sig. (2-tailed) 0,329>0,05. Berdasarkan hasil tersebut (terlihat pada tabel 5) dapat dikatakan bahwa tidak terdapat hubungan antara kesadaran pentingnya IT dengan indeks prestasi.

Tabel 5. Hasil Analisis Korelasi Kesadaran Pentingnya Teknologi Informasi dalam Menunjang Kesuksesan Terhadap Indeks Prestasi Belajar

\begin{tabular}{llrrr}
\hline & \multicolumn{1}{c}{ Correlations } & & \\
\hline & & IP & Important \\
\hline IP & Pearson Correlation & 1 & .271 \\
& Sig. (2-tailed) & & .329 \\
& $\mathrm{~N}$ & 15 & 15 \\
\hline Important & Pearson Correlation & .271 & 1 \\
& Sig. (2-tailed) & .329 & \\
& $\mathrm{~N}$ & 15 & 15 \\
\hline
\end{tabular}

2. Analisis yang sama dilakukan juga untuk mengetahui hubungan antara kesadaran akan adanya nilai tambah (value-added) IT terhadap indeks prestasi belajar mahasiswa (terlihat pada tabel 6). Hasil analisis diperoleh nilai Sig. (2-tailed) 0,863>0,05 yang artinya tidak terdapat hubungan antara kemampuan menemukan dan memilih referensi dengan memanfaatkan IT terhadap indeks prestasi mahasiswa calon guru fisika.

Tabel 6. Hasil Analisis Korelasi Kesadaran Akan Nilai Tambah (Value-Added) Teknologi Informasi Terhadap Indeks Prestasi Belajar

\begin{tabular}{llrr}
\hline & \multicolumn{1}{c}{ Correlations } & & \\
\hline IP & & IP & Value-Added \\
& Pearson Correlation & 1 & .088 \\
& Sig. (2-tailed) & & .756 \\
& $\mathrm{~N}$ & 15 & 15 \\
\hline Value-Added & Pearson Correlation & .088 & 1 \\
& Sig. (2-tailed) & .756 & \\
& $\mathrm{~N}$ & 15 & 15 \\
\hline
\end{tabular}

\section{Pembahasan}

Pendidikan calon guru fisika di STKIP Al Hikmah Surabaya sedikit berbeda dengan yang ada pada perguruan tinggi lainnya. Sistem pendidikan mengacu pada tiga aspek yang tidak bisa dipisahkan yaitu perkuliahan, sekolah, dan asrama. Selama pandemi seluruh tim baik dosen, manajemen, dan pengasuh berupaya tetap mempertahankan sistem pendidikan terintegrasi tersebut sekalipun dilaksanakan secara daring. Kegiatan perkuliahan dilaksanakan secara daring baik secara sinkron dan asinkron. Kegiatan 
interaksi edukatif dan asrama juga demikian dengan segala macam modifikasinya untuk menyesuaikan masa pandemi covid-19. Hal ini berimbas pada sistem penilaian untuk nantinya dikonversikan melalui DKN (Daftar Kumpulan Nilai) yang menyajikan Indeks Prestasi mahasiswa. Poin penting dari indeks prestasi mahasiswa tidak hanya diperoleh dari perkuliahan yang dilaksanakan daring. Akan tetapi juga berasal dari penilaian hasil interaksi edukatif dan pendidikan asrama. Pendidikan berasrama terbukti dapat memberikan penguatan karakter kepada peserta didik (Sarnoto, 2018). Penelitian lain menunjukkan bahwa adanya asrama dalam proses pendidikan terbukti berhubungan dengan pembentukan karakter (Ningsih, 2016). Sedangkan adanya interaksi edukatif, dimana mahasiswa sejak semester pertama sudah berinteraksi secara sistematis dan terjadwal secara teratur kesekolah dimaksudkan sebagai upaya meningkatkan kesiapan mahasiswa untuk terjun ke lembaga pendidikan pasca menyelesaikan studi. Program yang sejenis sebagai contoh praktik kerja lapangan terbukti lebih besar dampaknya terhadap kesiapan memasuki dunia kerja dibandingkan dengan prestasi belajar (Suryati et al., 2016). Sehingga uraian yang demikian menjadi tolok ukur dan pembanding bagaimana sistem penilaian yang dikembangkan, dimana prestasi belajar yang dimaksud di sini sedikit berbeda dengan prestasi belajar beberapa perguruan tinggi pada umumnya (perguruan tinggi pendidikan) dimana mengintegrasikan antara perkuliahan, interaksi edukatif ke dunia kerja, dan pendidikan asrama.

Berdasarkan hasil penelitian diperoleh hasil bahwa tidak terdapat pengaruh signifikan antara keterampilan IT terhadap prestasi belajar mahasiswa. Apabila dilakukan pengamatan secara sekilas hasil ini cenderung bertentangan dengan beberapa penelitian terkait sebelumnya. Damayanty (2016) misalnya, dalam penelitiannya menyebutkan bahwa keterampilan IT dalam hal ini kemampuan numerik terbukti meningkatkan prestasi belajar peserta didik. Kemampuan numerik IT berada pada salah satu aspek yaitu functional skill, dimana pada penelitian ini tidak terbuksi secara signifikan mempengaruhi prestasi belajar. Pada penelitian yang dilakukan (Gulek, 2004) terbukti bahwa penggunaan laptop dapat meningkatkan pencapaian hasil belajar peserta didik. Penelitian lain yang berkaitan dengan pengaruh literasi IT terhadap prestasi belajar mahasiswa juga memberikan bukti adanya hubungan positif antara kedua variabel tersebut (Siswoyoa, 2021). Pada ranah pembelajaran secara umum (Manshur, 2020) mengatakan bahwa terdapat korelasi yang signifikan antara penggunaan teknologi informasi terhadap prestasi belajar peserta didik. Namun demikian yang perlu dicermati adalah bahwa sistem penilaian pada perguruan tinggi ini sangatlah berbeda. Sistem penilaian mengintegrasikan antara perkuliahan, aktivitas interaksi edukatif, dan asrama. Hal ini yang membuat keterampilan IT seakan-akan tidak mempengaruhi prestasi belajar. Sistem penilaian yang berbeda salah satunya adalah porsi kedisiplinan dalam pengumpulan tugas, taat terhadap aturan dan format, akhlak dan etika selama perkuliahan, demikian juga ketika melakukan aktivitas interaksi edukatif di sekolah, akan dilaksanakan penilaian yang serupa terkait dengan kedisiplinan, sopan santun, komitmen dalam tugas, antusias dan semangat. Penelitian yang dilakukan oleh Intania (2020) membuktikan bahwa selama masa pendemi Covid-19 peran karakter sangatlah memegang peranan penting dalam pembelajaran. Sehingga memiliki keterampilan IT saja tidak cukup untuk mendapatkan nilai yang tinggi. Justru beberapa kasus dikarenakan memiliki pengetahuan IT yang luas tentang IT serta selama pandemi pembelajaran dilaksanakan secara daring, fokus mahasiswa menjadi terganggu. Hal ini didukung oleh penelitian yang pernah dilakukan oleh Attia (2017) bahwa laptop dan ponsel pintar dapat mengganggu konsentrasi peserta didik. Bahkan apabila peserta didik sudah berada pada status kecanduan informasi dan teknologi justru dapat menurunkan prestasi belajar (Septania, 2020). Terlebih lagi penguasaan IT yang tidak dapat meningkatkan prestasi belajar alih-alih justru terjadi penyalahgunaan (Abdullah et al., 2019).

Pengamatan lanjutan yang dilakukan terhadap mahasiswa program studi S-1 Pendidikan Fisika STKIP Al Hikmah Surabaya ternyata didapatkan fakta unik, yaitu mahasiswa yang memiliki keterampilan dan kesadaran teknologi informasi masuk dalam kategori tinggi, lebih kuat dalam menghadapi kompleksnya problem selama perkuliahan. Beberapa syarat yang harus dipenuhi ketika mahasiswa akan melakukan ujian skripsi diantaranya adalah nilai tes bahasa asing, hafalan, serta jumlah jam interaksi edukatif yang memenuhi. Banyaknya beban dan permasalah tersebut membuat mahasiswa yang memiliki keterampilan 
dan kesadaran IT kategori tinggi memiliki kelebihan dalam hal pengelolaan waktu, daya tahan terhadap tekanan, serta kompleksnya permasalahan yang dihadapi. Hal ini dibuktikan dengan mereka-mereka mahasiswa yang terlebih dahulu menyelesaikan syarat-syarat skripsi, dan telah menyelesaikan penelitian akhir, adalah mereka yang memiliki keterampilan dan kesadaran IT kategori tinggi. Beberapa penelitian ternyata juga membuktikan bahwa keterampilan IT dapat meningkatkan HOT (higher order thinking skills) (Ganapathy et al., 2017). Penelitian lain yang dilakukan (Nur'Aini, 2020) menyatakan bahwa kemampuan IT tidak berkaitan langsung dengan prestasi belajar, namun lebih berkaitan secara signifikan dengan kesiapan menghadapi kehidupan pasca kampus.

Pengamatan lebih detail yang dilakukan terhadap DKN mahasiswa ternyata ditemukan mahasiswa yang memiliki fungsional skill tinggi, juga mendapatkan nilai yang tinggi untuk matakuliah yang berkaitan langsung dengan pemrograman komputer. Begitupun juga dengan matakuliah-matakuliah yang lain, yang berkaitan langsung dengan aspek yang sesuai tentang keterampilan IT selalu dapat meningkatkan nilai matakuliah tersebut. Akan tetapi, satu matakuliah saja tidak cukup untuk membantu menaikkan indeks prestasi yang merupakan gabungan integrasi dari seluruh penilaian.

\section{Kesimpulan}

Berdasarkan hasil penelitian dan pembahasan maka dapat disimpulkan bahwa keterampilan dan kesadaran teknologi informasi tidak berpengaruh secara signifikan terhadap prestasi belajar mahasiswa selama perkuliahan daring pada semester gasal tahun akademik 2020/2021. Hal ini dikarenakan sistem penilaian komprehensif dan terintegrasi yang dilakukan oleh Program Studi Pendidikan Fisika STKIP Al Hikmah Surabaya. Penilaian prestasi mahasiswa yang direpresentasikan oleh Indeks Prestasi (IP) terdiri dari integrasi penilaian perkuliahan, penilaian interaksi edukatif, dan penilaian kegiatan asrama, sehingga peningkatan nilai akademik belum cukup untuk menaikkan prestasi belajar (IP) mahasiswa. Pada penelusuran data yang lebih detail ditemukan bahwa mahasiswa dengan aspek keterampilan teknologi informasi yang tinggi juga mendapatkan nilai tinggi pada matakuliah yang berhubungan langsung dengan aspek keterampilan teknologi informasi tersebut.

\section{Ucapan Terima Kasih}

Ucapan terimakasih disampaikan kepada LPPM STKIP Al Hikmah Surabaya yang berperan dalam pembinaan bagi peneliti, terimakasih yang sebesar-besarnya kepada seluruh dosen Program Studi S-1 Pendidikan Fisika STKIP Al Hikmah Surabaya yang telah menyediakan data nilai matakuliah mahasiswa, serta kepada mahasiswa Program Studi S-1 Pendidikan Fisika STKIP Al Hikmah Surabaya yang telah berpartisipasi aktif dalam penelitian ini.

\section{Referensi}

Abdullah, S., Mobonggi, A., Solong, N. P., \& Arif, M. (2019). Implikasi Teknologi Informasi Komunikasi terhadap Prestasi Belajar Peserta Didik pada Kelompok Mata Pelajaran Agama. Jurnal Ilmiah ALJauhari: Jurnal Studi Islam Dan Interdisipliner, 4(1). https://doi.org/10.30603/jiaj.v4i1.761

Afandi, R. (2011). Integrasi Pendidikan Karakter Dalam Pembelajaran IPS Di Sekolah Dasar. PEDAGOGIA: Jurnal Pendidikan. https://doi.org/10.21070/pedagogia.v1i1.32

Andiarna, F. (2020). Pengaruh Pembelajaran Daring terhadap Stres Akademik Mahasiswa Selama Pandemi Covid-19. Jurnal Psikologi, 16(2). https://doi.org/10.24014/jp.v16i2.10395

Arikunto, S. (2016). Prosedur Penelitian: Suatu Pendekatan Praktik. Edisi Revisi. Jakarta: Rineka Cipta. In Jurnal Ilmiah Farmasi Farmasyifa.

Attia, N. A., Baig, L., Marzouk, Y. I., \& Khan, A. (2017). The potential effect of technology and distractions on undergraduate students' concentration. Pakistan Journal of Medical Sciences, 33(4). https://doi.org/10.12669/pjms.334.12560

Damayanty, D. Y., \& Sumadi. (2016). Hubungan Antara Kemampuan Numerik, Kecerdasan Emosi dan 
Kemandirian Belajar dengan Prestasi Belajar Fisika Siswa. Jurnal Ilmiah Pendidikan Fisika, Volume 3 ,.

Daniel Hasibuan, M. T., Mendrofa, H. K., Silaen, H., \& Tarihoran, Y. (2020). Hubungan Motivasi Belajar Terhadap Prestasi Akademik pada Mahasiswa yang Menjalani Pembelajaran Daring Selama Pandemi COVID-19. Indonesian Trust Health Journal, 3(2). https://doi.org/10.37104/ithj.v3i2.65

Ganapathy, M., Kaur, M., \& Kaur, S. (2017). Tertiary students' learning practices using information and communication technology to promote higher-order thinking. Pertanika Journal of Social Sciences and Humanities, 25(2).

Gulek, J. C., \& Demirtas, H. (2004). Learning with technology: The impact of laptop use on student achievement. Journal of Technology, Learning, and Assessment, 3(2).

Hasanah, U., Ludiana, Immawati, \& PH, L. (2020). Gambaran Psikologis Mahasiswa Dalam Proses Pembelajaran Selama Pandemi Covid-19. Jurnal Keperawatan Jiwa, 8(3).

Intania, E. V. (2020). The role of character education in learning during the COVID-19 pandemic Peran pendidikan karakter dalam pembelajaran selama pandemi. Jurnal Penelitian Ilmu Pendidikan, 13(2).

Komalasari, R. (2020). Manfaat teknologi informasi dan komunikasi di masa pandemi covid 19. Tematik, 7(1). https://doi.org/10.38204/tematik.v7i1.369

Makmur, T. (2019). Teknologi Informasi. Info Bibliotheca: Jurnal Perpustakaan Dan Ilmu Informasi, 1(1). https://doi.org/10.24036/ib.v1i1.12

Manshur, A. (2020). Pengaruh Penggunaan Teknologi Informasi Dan Komunikasi Sebagai Media Pembelajaran Terhadap Prestasi Belajar Siswa Di Min Kepatihan Bojonegoro. At-Tuhfah, 9(1). https://doi.org/10.36840/jurnalstudikeislaman.v9i1.314

Mutiara, V. A. (2020). Teknologi Informasi Komunikasi dan Perkembangannya. Teknologi Informasi Komunikasi Dan Perkembangannya, 1(Perkembangan pada TIK).

Ningsih, S., \& Sugiaryo. (2016). Hubungan Pelaksanaan Full Day Sschool DAN Boarding School Dengan Pembentukan Karakter Pada Siswa Kelas XI MAN 1 Surakarta Tahun 2016/2017. Jurnal Global Citizen, 2(2).

Nur'Aini, D. (2020). Pengaruh penguasaan teknologi informasi dan prestasi belajar terhadap kesiapan kerja siswa SMK. Jurnal Pendidikan Manajemen Perkantoran, 5(2).

Puspitorini, F. (2020). Strategi Pembelajaran Di Perguruan Tinggi Pada Masa Pandemi Covid-19. Jurnal Kajian Ilmiah, 1(1). https://doi.org/10.31599/jki.v1i1.274

Sarnoto, A. Z. (2018). Pengaruh Kecerdasan Jamak Dan Sekolah Berasrama Terhadap Karakter Siswa. Profesi | Jurnal Ilmu Pendidikan Dan Keguruan, 7(1).

Sembiring, A. B. (2021). Persepsi Siswa SMA Selama Pembelajaran Daring Saat Pandemi Covid-19. Koneksi, 5(1). https://doi.org/10.24912/kn.v5i1.10191

Septania, S., \& Proborini, R. (2020). Self-Compassion, Grit dan Adiksi Internet pada Generasi Z. Analitika, 12(2). https://doi.org/10.31289/analitika.v12i2.4175

Setiawan, H. S. (2018). Pelatihan Guru dalam Penggunaan Internet of Things pada Madrasah Darussa'adah. E-Dimas: Jurnal Pengabdian Kepada Masyarakat. https://doi.org/10.26877/e-dimas.v9i2.1554

Siswoyoa, \& Muliyati, D. (2021). Relationship between information and communication technology literacy and the of english ability with learning outcomes of students of physics education program, fmipa unj. AIP Conference Proceedings, 2320. https://doi.org/10.1063/5.0037486

Sujana, I. W. C. (2019). Fungsi dan Tujuan Pendidikan Indonesia. Adi Widya: Jurnal Pendidikan Dasar, 4(1). https://doi.org/10.25078/aw.v4i1.927

Suryati, L., Agustunin, R. S., \& Sucipto, T. L. A. (2016). Pengaruh Praktik Kerja Lapangan Dan Prestasi Belajar Terhadap Kesiapan Memasuki Dunia Kerja Pada Siswa Kelas Xi Program Keahlian Teknik Gambar Bangunan Smk N 5 Surakarta Tahun Pelajaran 2016/2017. Indonesian Journal Of Civil Engineering Education, 3(1). https://doi.org/10.20961/ijcee.v3i1.22418

Zulfah, S. (2018). Pengaruh Perkembangan Teknologi Informasi Lingkungan (Studi Kasus Kelurahan Siti Rejo I Medan). Buletin Utama Teknik, 13(2). 
Edu Cendikia: Jurnal Ilmiah Kependidikan

Volume : 1 | Nomor 2 | Agustus 2021 | E-ISSN : 2798-365X | DOI: 10.47709/educendikia.v1i2.1024 